\title{
Public Participation to Improve Road Society
}

\author{
Mohamad Ghazali Masuri1', Akehsan Dahlan'1, \\ Ajau Danis², Khairil Anuar Md Isa² \\ 1 Occupational Therapy Department, \\ 2 Basic Sciences Department, \\ Faculty of Health Sciences, Universiti Teknologi MARA, Malaysia. \\ zalie222@gmail.com
}

\begin{abstract}
Road traffic accident (RTA) frequently involves multi-level society and this has become a demanding community issue where more serious participation is needed to improve driver's attitude in the future. RTA has a significant impact on quality of life and financial burden to the government and Malaysian society. There is limited local evidence supporting the elements of driver's attitudes. This concept paper will discuss a potential method to be used in developing valid and sensitive driver's evaluation. This evaluation may help the government to produce better road users in the future.
\end{abstract}

Keywords: Public attitude; road society in the future; save drivers

eISSN 2398-4295 @ 2018. The Authors. Published for AMER ABRA CE-Bs by e-International Publishing House, Ltd., UK. This is an open-access article under the CC BY-NC-ND license (http://creativecommons.org/licenses/by$n c-n d / 4.0 /$ ). Peer-review under responsibility of AMER (Association of Malaysian Environment-Behaviour Researchers), ABRA (Association of Behavioural Researchers on Asians) and CE-BS (Centre for EnvironmentBehaviour Studies), Faculty of Architecture, Planning \& Surveying, Universiti Teknologi MARA, Malaysia.

DOI: http://dx.doi.org/10.21834/ajbes.v3i10.88 


\subsection{Introduction}

Driving is an intricate daily activity that involves active eye, hand, and foot coordination. Drivers who fail to organize and interact with machine and environment may lead to road traffic injury (RTI) (Masuri, Isa, \& Tahir, 2012). According to (Alert Driving Megazine, 2011), $90 \%$ of road traffic accidents were caused by human error. This made the human error as an important ergosystem component that needs to be further investigate. Road users who use the road either for leisure or work purposes usually expose to the risk of accident/injury. According to Royal Malaysia Police, the major proportion of fatal accidents was caused by motorcyclists followed by 4-wheels. Since 2002 for five consecutive years, fatal accidents have remained the number one cause of road traffic casualty (Royal Malaysian Police, 2007). An accident involving road transport has a significant impact on person quality of life and financial burden to the government and our society. According to Malaysian Institute of Road Safety (MIROS), a model has been predicted the fatalities for the year 2015 are 8,760 while for the year of 2020 will be increased to 10,716 (Sarani, Rahim, Jamilah Mohd Marjan, \& Wong Shaw Voon, 2012). The number of RTA is increasing and addresses significant demands for better action. Many studies had proven that human factor was identified as a significant contribution to RTA. The question arose either the existing driving syllabus and licensing process addresses psychological and physiological domains to be a fit driver? Does the syllabus and training address sufficient knowledge, affective, psychomotor and soft skills to the drivers? Does it measurable? It may need to be reviewed and transform into a new format. What if the license that we have does not prepare us to be a fit, safe and health drivers? Then, the government may allow risky and reckless drivers on the road. Many interventions such as increasing the amount of summons which aims to educate the drives had seen no changes in driver's behavior. However, this intervention seems far to be concluded as successful. Using sound measurement strategies enables professionals to include individuals and their families in the process of selecting the most compatible and effective interventions for them With regards to driving assessment, there are many drivers related assessments available worldwide. However, these assessments varied from one and another. This study suggests, being able to choose or design appropriate intervention, highly sensitive and significant assessment is vital. This demand for more universal and standardized assessment which can be used and understand locally and perhaps globally. It is impossible to create single attitude assessment related to driving that fits all due to the complexity of human behavior including driving activity (Masuri, Isa, \& Tahir, 2012) itself, yet 'local norm' related to high/low-risk drivers should be establish as fundamental references for further research. This proactive approach may be able to estimate the future trends of RTA and at the same time to prepare the nation in achieving Vision 2020. Valid, sensitive and reliable assessment is needed to identify the human component that relates with RTA. Currently, there is no local assessment available to assess Malaysian driver's attitude towards save driving behavior. This study believes programs that focusing on attitude change will have a better prospect to address the fundamental cause of RTA. 


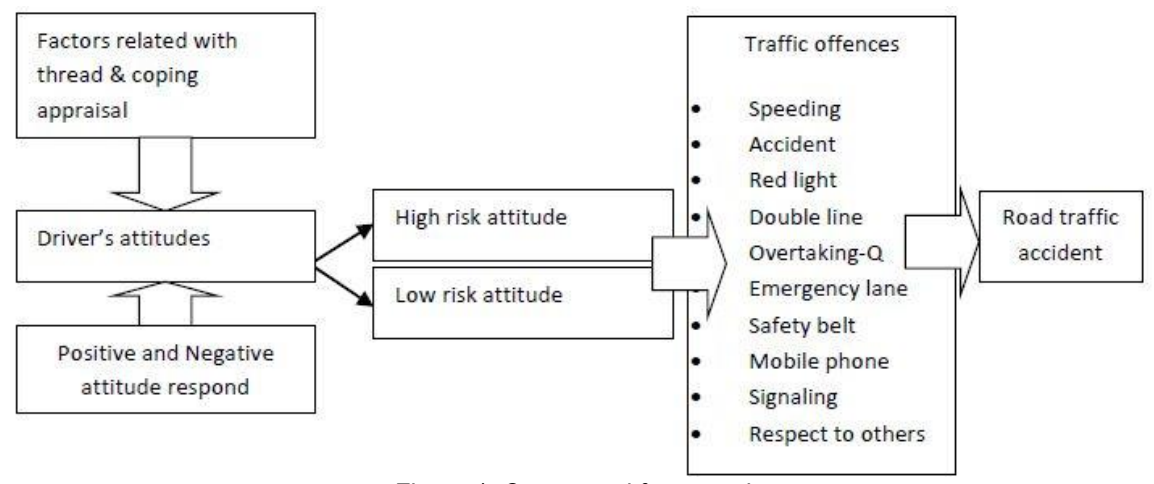

Figure 1: Conceptual framework.

\subsection{Literature Review}

Many studies have proven that attitudes rarely present the synchronize behavior. Attitudes can be presented either in positive or negative form. Even though attitude and behavior were not usually straightforward and they are sensitive according to a social situation, but, attitude assessment can be used to predict future behavior (Iversen, 2004). To promote appropriate intervention in reducing RTA is is vital to understand the human attitudes relates to driving behavior. Currently, many kinds of literature claim that accident caused by human error yet, the limited evidence available to justify which human components are needed to be address. Previous study shows that, different factors such as sociodemographic issues (Al-Naggar, Bobryshev, \& Mohd Noor, 2013), socioeconomic status (Goldzweig et al., 2013; Masuri, Isa, \& Tahir, 2012), rural/urban location (Eiksund, 2009), age/gender (Scott-Parker, Watson, King, \& Hyde, 2012), education level (Masuri et al., 2012), living status (Al-Naggar, et al., 2013) and personality (Chen, 2009) brought significant effects on driving behavior. However, those assessments were not environmental and culturally sensitive to Malaysian population. Some of it was focusing on engineering control and lacking of human components. To date, there is no specific attitude assessment developed locally. This demand for more valid and reliable attitude scale which should address the uniqueness and sensitivity of Malaysian drivers.

\section{Public participation in shaping better Malaysian's road society in the future.}

RTA in Malaysia frequently involves multi-level society, and this has become a demanding community issue where more serious community participation is needed to improve the future. Some literature shows that these accidents were caused by human error. As mentioned earlier, RTA has a significant impact on person quality of life and financial burden to the government and Malaysian society. It is not solely the government responsibility to improve the quality of life and to achieve the status of the developed country. Public participation is to a large extent were needed in shaping a better future in the road and transportation system in Malaysia. This study is critical in developing valid and culturally 
sensitive attitude assessment for young Malaysian drivers. Standardized assessment should be able to help the government to refer to the identical and valid information. With regards to professional perspective, the use of standardized assessments is essential in helping to improve the quality and quantity of information for making an accurate decision. It also enables professional bodies to evaluate occupational performance outcomes and help people achieve their objectives.

\subsection{Methodology}

The process of literature search involves literature searching from on line journal, hard copy, books, newspaper and other internet based resources. Few search engines were used during the on line searching. The most common on line database used were Googlescholar.com, Medline database, Cochrane review, Royal Malaysia Police, MIROS Malaysia, JKJR.com, thesis on line, WHO website, the local newspaper, onthescene.com and sciencedirect.com. The scope of this study will focus on driving attitudes that contribute to either high or low risk driving behavior. This study will limit the investigation based on five major risk factors as stated in the global status report on road safety 2013 by WHO; speed, drink-driving, helmet, seat belt, child restraint (Jabatan Keselamatan Jalan Raya Malaysia, 2013) and other six offences that lead to maximum penalties (Road Transport Act 1987): exceeding speed limit, involve with traffic accident, disobey stop signal - red light, overtaking at double line, overtaking others in queue and using an emergency lane/left lane (Royal Malaysian Police, 2007). Since some factors such as drink-driving, wearing helmet and child restrain neither were nor meet with inclusion criteria, these factors will be excluded from this study. Another three factors such as mobile phone usage, signalling and respect to others was added based on researcher previous study (Isa et al., 2012).

\section{Data analysis.}

The first stage of data analysis (qualitative approach), data analysis will be done simultaneously with ongoing data collection. The data on focus group will be analyzed based on thematic analysis. Based on two processes of thematic analysis, theme emerge will be further explored, and interview will be discontinued once the theme has saturated. Atlas.ti. The software will be used in the process of transcribing the interview, segmentation, and coding as well as the building of conceptual network (Muhr, 1991). The second stage of data analysis, questionnaires validity will be analyze using Rasch model. The Rasch model will produce items and individual separation index (Ariffin, Omar, Isa, \& Sharif, 2010). This index will be further used in analyzing the fit item with the individual. To identify two category of ASDS result (low or high-risk drivers), receiver operating characteristic (ROC) curves will be used to determine a cutoff value. For the final stage of data analysis, this study will engage in SPSS version 19 (or above) to correlate the paper based score (ASDS- low or high-risk drivers) with participant performance in driving simulation test. Participant driving behavior will only be observed after 3 minutes from the time of simulation begin. This will allow the participant to be settled and to control observed behavior. Cronbach alpha coefficient will be used to evaluate the internal consistency of the driving simulation. Structure Equations Model 
(SEM) correlation matrix and structural model will be estimated with the maximum likelihood technique. Two steps approach of SEM, which involves Confirmatory Factor Analysis (CFA) used to evaluate the measurement model and fit index. The appropriate fit index such as goodness-of-fit index (GFI), adjusted goodness-of-fit index (AGFI), comparative fit index (CFI) and root mean square error of approximation (RMSEA) will be used accordingly ( Table 1).

Table 1: Methods and data analysis table.

\begin{tabular}{|c|c|c|c|c|c|c|}
\hline Stage & $\begin{array}{l}\text { Aim } \\
\text { objectives }\end{array}$ \& & Method & Sampling & Sample size & Inclusion/exclusion & Analysis \\
\hline $\begin{array}{l}\text { Stage 1: } \\
\text { One-to-one } \\
\text { interview }\end{array}$ & $\begin{array}{l}\text { To identify } \\
\text { participant } \\
\text { respond } \\
\text { towards high } \\
\text { and low risk } \\
\text { driving } \\
\text { behavior } \\
\text { among } \\
\text { Malaysian } \\
\text { young adult } \\
\text { To investigate } \\
\text { themes that } \\
\text { related to the } \\
\text { topic } \\
\text { To translate } \\
\text { themes into } \\
\text { questionnaire }\end{array}$ & $\begin{array}{l}\text { Semi } \\
\text { structured } \\
\text { interview }\end{array}$ & $\begin{array}{l}\text { Purposive } \\
\text { sampling } \\
\text { method }\end{array}$ & $1-10$ & $\begin{array}{l}\text { Malaysian } \\
\text { Experience RTA } \\
\text { OR } \\
\text { Witness (on the } \\
\text { scene) }\end{array}$ & $\begin{array}{l}\text { Atlas.ti } \\
\text { software }\end{array}$ \\
\hline $\begin{array}{l}\text { Stage 2: } \\
\text { Psychometric } \\
\text { validation of } \\
\text { the } \\
\text { questionnaire }\end{array}$ & $\begin{array}{l}\text { To validate the } \\
\text { Attitude } \\
\text { towards Save } \\
\text { Driving Scale } \\
\text { To investigate } \\
\text { the } \\
\text { psychometric } \\
\text { properties of } \\
\text { the } \\
\text { questionnaire } \\
\text { To identify the } \\
\text { cut-off value } \\
\text { between high } \\
\text { and low risk } \\
\text { drivers }\end{array}$ & $\begin{array}{l}\text { Standard } \\
\text { protocol } \\
\text { suggested by } \\
\text { development } \\
\text { and } \\
\text { validation } \\
\text { process }\end{array}$ & $\begin{array}{l}\text { Purposive } \\
\text { sampling yet } \\
\text { different } \\
\text { participant } \\
\text { between } \\
\text { EFA and } \\
\text { CFA } \\
\text { analysis }\end{array}$ & $\begin{array}{l}\text { Minimum } 5 \\
\text { for each } \\
\text { questions, } \\
\text { or } 100\end{array}$ & $\begin{array}{l}\text { Malaysian } \\
\text { Age between 18-24 } \\
\text { Having a valid D } \\
\text { class } \\
\text { Malaysia Driving } \\
\text { license } \\
\text { Able to read and } \\
\text { understand simple } \\
\text { English and Malay } \\
\text { Physically and } \\
\text { mentally fit on the } \\
\text { day of assessment. }\end{array}$ & \\
\hline $\begin{array}{l}\text { Phase 1: } \\
\text { Evaluation of } \\
\text { content and } \\
\text { face validity }\end{array}$ & $\begin{array}{l}\text { To evaluate } \\
\text { the face and } \\
\text { content of the } \\
\text { assess }\end{array}$ & $\begin{array}{l}\text { Field expert } \\
\text { review } \\
\text { Face validity } \\
\text { test }\end{array}$ & & & & $\begin{array}{l}\text { Expert } \\
\text { review } \\
\text { panels } \\
\text { Target } \\
\text { group } \\
\text { review }\end{array}$ \\
\hline $\begin{array}{l}\text { Phase 2: } \\
\text { Internal } \\
\text { consistency }\end{array}$ & $\begin{array}{l}\text { To investigate } \\
\text { the internal } \\
\text { consistency of } \\
\text { the } \\
\text { questionnaire }\end{array}$ & $\begin{array}{l}\text { Statistical } \\
\text { analysis }\end{array}$ & & & & $\begin{array}{l}\text { Test Re- } \\
\text { test } \\
\text { ICC- } \\
\text { Kappa, } \\
\text { ROC } \\
\end{array}$ \\
\hline
\end{tabular}


Masuri, M.G., et.al. / Asian Journal of Behavioural Studies (AjBeS), 3(10) Mar / Apr 2018 (p. 137-145)

\begin{tabular}{|c|c|c|c|c|c|c|}
\hline & & & & & & $\begin{array}{l}\text { curve and } \\
\text { cut-off } \\
\text { value } \\
\text { Cronbach } \\
\text { Alpha } \\
\text { value }\end{array}$ \\
\hline $\begin{array}{l}\text { Phase 3: } \\
\text { Construct } \\
\text { validity }\end{array}$ & $\begin{array}{l}\text { To validate the } \\
\text { construct of } \\
\text { the } \\
\text { questionnaire }\end{array}$ & $\begin{array}{l}\text { Statistical } \\
\text { analysis }\end{array}$ & & & & $\begin{array}{l}\text { Pearson } \\
\text { correlation } \\
\text { CFA } \\
\text { EFA } \\
\text { Rasch } \\
\text { model }\end{array}$ \\
\hline $\begin{array}{l}\text { Stage 3: } \\
\text { Correlation of } \\
\text { questionnaire } \\
\text { and STSIM } \\
\text { driving } \\
\text { simulation }\end{array}$ & $\begin{array}{l}\text { To correlate } \\
\text { the } \\
\text { questionnaire } \\
\text { score with } \\
\text { driving } \\
\text { simulation } \\
\text { To identify any } \\
\text { relationship } \\
\text { between } \\
\text { attitude and } \\
\text { behavior } \\
\text { under lab } \\
\text { situation }\end{array}$ & $\begin{array}{l}\text { Statistical } \\
\text { analysis }\end{array}$ & $\begin{array}{l}\text { Purposive } \\
\text { sampling } \\
\text { method } \\
\text { Compulsory } \\
\text { to attend } \\
\text { stage } 2 \text {. }\end{array}$ & $\begin{array}{l}80 \quad \text { with } \\
\text { expected } \\
\text { stage } 2 \\
\text { participant } \\
\text { is } 100 \text {, } \\
\text { marginal } \\
\text { error } 5 \% \text {, } \\
\text { confidence } \\
\text { level at } \\
95 \% \text {, } \\
\text { response } \\
\text { distribution } \\
\text { is } 50-50 \%\end{array}$ & $\begin{array}{l}\text { Ability to sit with a } \\
\text { minimum of } 15 \\
\text { minutes without sit- } \\
\text { to-stand or sit } \\
\text { shifting demand - } \\
\text { pregnant woman } \\
\text { may participate if } \\
\text { she pass the test } \\
\text { Has no previous } \\
\text { experience either } \\
\text { minor or major road } \\
\text { accident for the last } \\
12 \text { months. } \\
\text { *including criteria } \\
\text { from stage } 2 \text {. }\end{array}$ & $\begin{array}{l}\text { SPSS v.19 } \\
\text { or above. }\end{array}$ \\
\hline
\end{tabular}

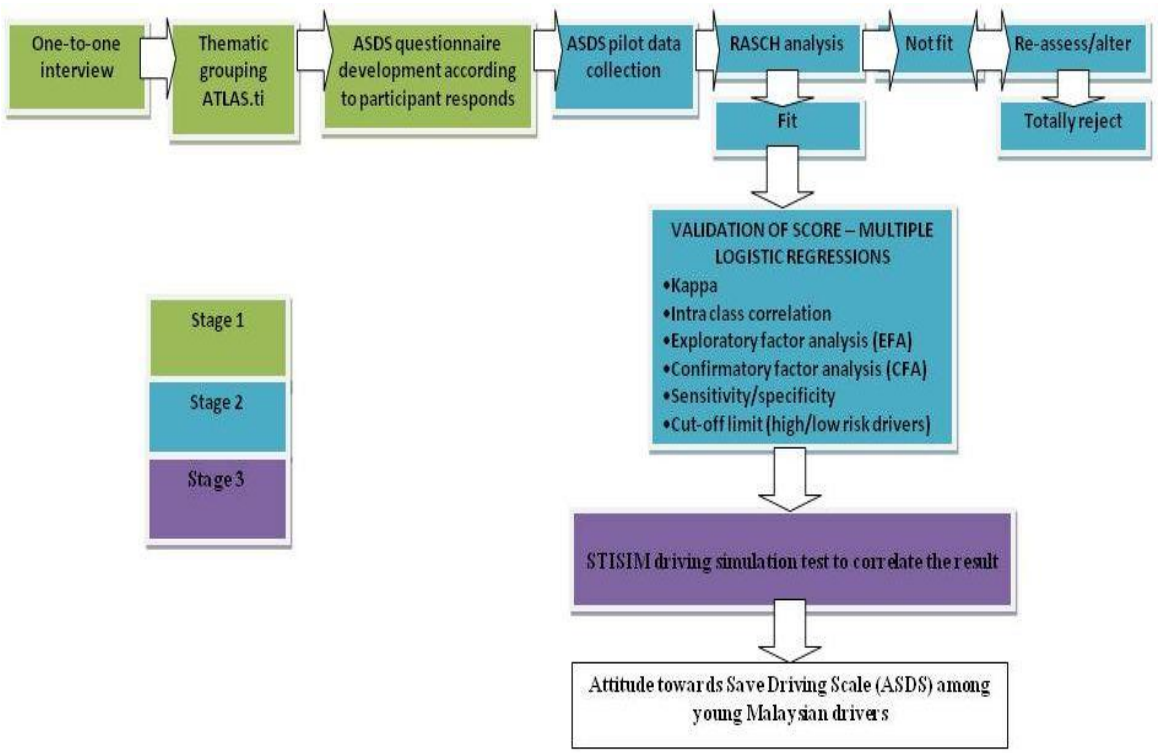

Figure 2: Overview of the statistical analysis 


\subsection{Results and Discussions}

\section{Stage 1}

For the qualitative process, focus group interview will be conducted to explore and generate further question in developing the ASDS. ATLAS.ti software will be used to manage the respondent data. Questions will be developed according to the theme emerges. Some of the interview components will be focus on the factors as stated on PMT. Semi-structured interview - direction of interview according to components in (Isa, et al., 2012; Jabatan Keselamatan Jalan Raya Malaysia, 2013; Royal Malaysian Police, 2007). Propose model of interview based on (Chen, 2009; Lund \& Aarø, 2004; Wu, Stanton, Li, Galbraith, \& Cole, 2005).

\section{Stage 2}

Questionnaire development of ASDS will be based on participant respondent according to appropriate theme. This design will involve pilot study and questionnaire validation. The ASDS will be piloted, and the result will be analyzed. The total number of the participant will be identifying once the first stage of questionnaire development has completed. Rasch analysis will be conducted to validate the questionnaires.

\section{Stage 3}

The final stage will involve driving simulation experiment (STISIM protocol) to validate the result with ASDS score. A participant who involved on stage 2 will be encouraged to participate in the driving simulation test Purposeful sampling method). Phone call/SMS method will be practice as a follow-up method. To correlate the ASDS and driving performance, simulation test will be conducted to the participant who had involved on stage 2. They will be called to sit for the simulation test. Participant driving ability will be tested using a standard driving simulation STISIM M400 - USA, California. All testing will take place between 9.00 a.m. to 12.00 p.m. (real time), and each participant will go through a standard testing protocol.

\subsection{Conclusion}

With regards to Malaysian road safety research and development, this paper would like to claim that, this propose study method is novel and unique. The expected outcome from this research is an assessment and model that will be able to measure save attitude among young Malaysian drivers. This evaluation can be used in screening and re-evaluation process of licensing in Malaysia. This evaluation also will be able to help the government in producing a better road society in the future.

\section{Acknowledgement}

This study would like to thank the Research Management Institute (RMI) and all staff of the 
Faculty of Health Sciences UiTM Puncak Alam for continuous support in staff research and development. This study Iso would like to thank the Land Public Transport Commission also known as SPAD and PROTON Professor Office for their direct and indirect support. This study were funded by Fundamental Research Grant Scheme (FRGS) under the Ministry of Education (MOE) Malaysia; (600-RMI/FRGS 5/3 (118/2013).

\section{References}

Al-Naggar, R. A., Bobryshev, Y. V., \& Mohd Noor, N. A. B. (2013). Lifestyle practice among Malaysian university students. Asian Pacific Journal of Cancer Prevention, 14(3), 1895-1903.

Alert Driving Megazine. (2011). Human error accounts for $90 \%$ of road accidents. International News, from http://www.alertdriving.com/home/fleet-alert-magazine/international/human-error-accounts-90-road-accidents

Ariffin, S. R., Omar, B., Isa, A., \& Sharif, S. (2010). Validity and reliability multiple intelligent item using rasch measurement model. Procedia - Social and Behavioral Sciences, 9(0), 729-733. doi: http://dx.doi.org/10.1016/j.sbspro.2010.12.225

Chen, C.-F. (2009). Personality, safety attitudes and risky driving behaviors-Evidence from young Taiwanese motorcyclists. Accident Analysis \& Prevention, 41(5), 963-968. doi: http://dx.doi.org/10.1016/j.aap.2009.05.013

Eiksund, S. (2009). A geographical perspective on driving attitudes and behaviour among young adults in urban and rural Norway. Safety Science, 47(4), 529-536.

Goldzweig, I. A., Levine, R. S., Schlundt, D., Bradley, R., Jones, G. D., Zoorob, R. J., et al. (2013). Improving seat belt use among teen drivers: Findings from a service-learning approach. Accident Analysis and Prevention, 59(2013), 71-75.

Isa, K. A. M., Masuri, M. G., Abd Aziz, N. A., Isa, N. N. M., Hazali, N., Tahir, M. P. M., et al. (2012). Mobile Phone Usage Behaviour while Driving among Educated Young Adults in the Urban University. Procedia - Social and Behavioral Sciences, 36(0), 414-420. doi: http://dx.doi.org/10.1016/j.sbspro.2012.03.045

Iversen, H. (2004). Risk-taking attitudes and risky driving behaviour. Transportation Research Part F: Traffic Psychology and Behaviour, 7(3), 135-150. doi: http://dx.doi.org/10.1016/j.trf.2003.11.003

Jabatan Keselamatan Jalan Raya Malaysia. (2013). Global status report on road safety 2013: supporting a decade of action Retrieved 10 August 2013, 2013, from http://www.jkj.gov.my/ms/maklumat_keselamatan/statistik/funcstartdown/33/

Lund, J., \& Aarø, L. E. (2004). Accident prevention. Presentation of a model placing emphasis on human, structural and cultural factors. Safety Science, 42(4), 271-324. doi: 10.1016/s0925-7535(03)00045-6

Masuri, M. G., Isa, K. A. M., \& Tahir, M. P. M. (2012). Children, Youth and Road Environment: Road Traffic Accident. Procedia - Social and Behavioral Sciences, 38(0), 213-218. doi: http://dx.doi.org/10.1016/j.sbspro.2012.03.342

Masuri, M. G., Isa, K. A. M., Tahir, M. P. M., Hassan, H. F., Hassan, Z., Jamhuri, F. Z., et al. (2012). Behaviour Response among Health Sciences Students towards H1N1 Pandemic. Procedia - Social and Behavioral Sciences, 36(0), 77-86. doi: 10.1016/j.sbspro.2012.03.009

Muhr, T. (1991). ATLAS/ti - A prototype for the support of text interpretation. Qualitative Sociology, 14(4), 349-371. 
doi: 10.1007/bf00989645

Royal Malaysian Police. (2007). Road traffic accident and fatality statistics. Retrieved 27 August 2012, 2012, from http://www.rmp.gov.my/

Sarani, R., Rahim, S. A. S. M., Jamilah Mohd Marjan, P., \& Wong Shaw Voon, P. (2012). Predicting Malaysian Road Fatalities for Year 2020.

Scott-Parker, B., Watson, B., King, M. J., \& Hyde, M. K. (2012). Confirmatory factor analysis of the Behaviour of Young Novice Drivers Scale (BYNDS). Accident Analysis \& Prevention, 49(0), 385-391. doi: http://dx.doi.org/10.1016/j.aap.2012.02.021

Wu, Y., Stanton, B. F., Li, X., Galbraith, J., \& Cole, M. L. (2005). Protection Motivation Theory and Adolescent Drug Trafficking: Relationship between Health Motivation and Longitudinal Risk Involvement. Journal of Pediatric Psychology, 30(2), 127-137. 